\title{
Gordonia shandongensis sp. nov., isolated from soil in China
}

\author{
Hongli Luo, ${ }^{1,2}$ Oiang Gu, ${ }^{1}$ Jianping Xie, ${ }^{2}$ Changhua $\mathrm{Hu}^{2}$ Zhiheng Liu ${ }^{1}$ \\ and Ying Huang ${ }^{1}$ \\ ${ }^{1}$ State Key Laboratory of Microbial Resources, Institute of Microbiology, Chinese Academy of \\ Sciences, Beijing 100080, China \\ ${ }^{2}$ Institue of Modern Biopharmaceuticals, School of Life Science, Southwest University, \\ Chongqing 400715, China
}

\begin{abstract}
The taxonomic position of strain SD29 ${ }^{\top}$, isolated from soil, was clarified using a polyphasic taxonomic approach. The organism produced an elementary branching mycelium which fragmented into rod/coccus-shaped elements and it possessed meso-diaminopimelic acid, arabinose, galactose as diagnostic diamino acid and sugars, MK- $9\left(\mathrm{H}_{2}\right)$ as predominant menaquinone, phospholipids of type PII and mycolic acid. Phylogenetic analysis based on 16S rRNA gene sequences revealed that strain $\mathrm{SD}_{2}{ }^{\top}$ was most closely related to Gordonia hydrophobica DSM $44015^{\top}$ and Gordonia sihwensis DSM $44576^{\top}$, forming a distinct but loosely related branch in the phylogenetic tree. A number of physiological properties readily separated the isolate from its nearest neighbours. It is evident from genotypic and phenotypic data that strain $\mathrm{SD}_{2}{ }^{\top}$ represents a novel species of the genus Gordonia, for which the name Gordonia shandongensis sp. nov. is proposed. The type strain is SD29 ${ }^{\top}\left(=\mathrm{CGMCC} 4.3492^{\top}=\mathrm{JCM} 13907^{\top}\right.$ ).
\end{abstract}

The genus Gordonia (formerly Gordona), proposed by Tsukamura (1971), belongs to the mycolic acid group of the actinomycetes and the suborder Corynebacterineae and forms a distinct phyletic line in the 16S rRNA gene phylogenetic tree (Stackebrandt et al., 1988, 1997). The genus encompasses 25 species with validly published names at the time of writing (November 2006), which can be distinguished from each other using a combination of morphological, physiological and chemical markers (Goodfellow et al., 1999).

Several members of this taxon were isolated from clinical samples and have been considered as opportunistic human pathogens (Tsukamura, 1971; Klatte et al., 1994; Iida et al., 2005; Kageyama et al., 2006). Nevertheless, most gordoniae have been isolated from other environments such as mangrove rhizosphere, soil, wastewater, oil-producing wells and activated sludge foam (Takeuchi \& Hatano, 1998; Kummer et al., 1999; Kim et al., 2003; Maldonado et al., 2003; Xue et al., 2003; Shen et al., 2006; Soddell et al., 2006) and play important roles in pollutant biodegradation and bioremediation (Yoon et al., 2000) because of their abilities to metabolize macromolecules or contaminants, for example natural rubber, benzothiophene and hydrocarbons (Linos et al., 1999; Kim et al., 1999; Xue et al., 2003). It is therefore important for ecological reasons to unravel the species-richness of gordoniae in nature habitats. The aim

The GenBank/EMBL/DDBJ accession number for the 16S rRNA gene sequence of strain $\mathrm{SD}^{\top} 9^{\top}$ is DQ420167. of this study is to clarify the taxonomic position of a rod/ coccus-like strain isolated from farmland soil.

Strain SD29 ${ }^{\mathrm{T}}$ was isolated on ISP 2 agar (Shirling \& Gottlieb, 1966), supplemented with $50 \mu \mathrm{g}$ cycloheximide $\mathrm{ml}^{-1}$, which had been incubated for 5 days at $28^{\circ} \mathrm{C}$ following inoculation with a suspension of soil sample collected from farmland in Shandong Province, China. The pure cells were stored in $20 \%$ (v/v) glycerol at $-20{ }^{\circ} \mathrm{C}$. Biomass for chemotaxonomic study was harvested by centrifugation after 3 days at $28{ }^{\circ} \mathrm{C}$ in shake flasks of ISP 2 and TSB (trypticase soy broth), washed twice with distilled water and freeze-dried. Control type strains Gordonia hydrophobica DSM $44015^{\mathrm{T}}$ and Gordonia sihwensis DSM $44576^{\mathrm{T}}$ were incubated as described above.

Colonial characteristics of strain SD29 ${ }^{\mathrm{T}}$ were observed on ISP 2 agar. Zeihl-Neelsen staining (Gordon, 1967) and morphological properties were recorded using a light microscope (Axioskop 20; Zeiss) and scanning electron microscope (FEI QUANTA) after 5 days on ISP 2 plates. The ability to utilize sole carbon sources for energy and growth and to decompose various substances was assessed according to the methods of Gordon \& Mihm (1957). Standard chemotaxonomic analytical procedures were used as follows: Hasegawa et al. (1983) [isomers of diaminopimelic acid $\left(\mathrm{A}_{2} \mathrm{pm}\right)$ ], Lechevalier \& Lechevalier (1980) (whole-cell sugars), Collins (1985) and Wu et al. (1989) (menaquinones), Minnikin et al. (1984) (polar lipids), Sasser (1990) and Kämpfer \& Kroppenstedt (1996) (fatty acids) and Minnikin et al. (1975) (mycolic acids). 
Extraction of whole genomic DNA, PCR amplification of the $16 \mathrm{~S}$ rRNA gene and sequencing of the PCR product were performed as described previously (Chun \& Goodfellow, 1995; Huang et al., 2001). The almost-complete $16 \mathrm{~S}$ rRNA gene sequence (1398 nt) of strain SD29 ${ }^{\mathrm{T}}$ was aligned with corresponding sequences of all type strains within the genus Gordonia retrieved from GenBank using MEGA software version 3.1 (Kumar et al., 2004). Phylogenetic trees were constructed using the neighbour-joining (Saitou \& Nei, 1987) and maximum-parsimony (Fitch, 1971) methods. Evolutionary distances for the neighbour-joining algorithm were calculated with the Kimura two-parameter model (Kimura, 1980) and close-neighbour-interchange (search level $=2$, random additions $=100$ ) was applied in the maximum-parsimony analysis. The topology of the neighbour-joining tree was evaluated by bootstrap analysis on the basis of 1000 replications (Felsenstein, 1985).

The morphological and chemotaxonomic characteristics of strain SD29 ${ }^{\mathrm{T}}$ were consistent with the diagnostic properties of the genus Gordonia (Stackebrandt et al., 1988). The organism was Gram-positive, aerobic, non-motile and slightly acid-fast, formed short elementary mycelia that separated into rod/coccus-shaped elements and produced light-yellow, rough colonies, different in appearance from the control type strains, on ISP 2 agar. It contained meso$\mathrm{A}_{2} \mathrm{pm}$, arabinose and galactose in whole-cell hydrolysates (cell-wall chemotype IV sensu Lechevalier \& Lechevalier, 1970), MK-9 $\left(\mathrm{H}_{2}\right)$ as the predominant menaquinone and phosphatidylethanolamine, diphosphatidylglycerol, phosphatidylinositol and phosphatidylinositol mannosides as diagnostic polar lipids (phospholipid type II sensu Lechevalier et al., 1977). The mycolic acid pattern detected by TLC was identical to that of the control strain G. sihwensis DSM $44576^{\mathrm{T}}$. The fatty acid profile was composed mainly of $\mathrm{C}_{14: 0}$ $(3.5 \%), \mathrm{C}_{15: 0}$ iso $2-\mathrm{OH}(14.6 \%), \mathrm{C}_{16: 0}(35.9 \%), \mathrm{C}_{18: 1} \omega 9 c$ $(21.3 \%)$ and TBSA (tuberculostearic acid, 10-methyl $\mathrm{C}_{18: 0}$ ) $(14.9 \%)$ and differed from those of related type strains in the presence of a significant amount of $\mathrm{C}_{15: 0}$ iso $2-\mathrm{OH}$ (Table 1).

Results based on BLAST searches with the 16S rRNA gene sequence against the GenBank/EMBL/DDBJ databases showed that strain $\mathrm{SD} 29^{\mathrm{T}}$ was closely related to members of the genus Gordonia. It lay in a monophyletic clade with $G$. sihwensis DSM $44576^{\mathrm{T}}$ and G. hydrophobica DSM $44015^{\mathrm{T}}$ in the neighbour-joining tree (Fig. 1), and shared the highest 16S rRNA gene sequence similarity (97.1 and 97.0\%, respectively) with these strains. Such low similarity values and the low bootstrap levels (37 and $40 \%$ ) supporting the clades indicated that the isolate was distinct from the type strains of $G$. sihwensis and G. hydrophobica. In the maximum-parsimony tree, the isolate formed an unstable clade (bootstrap level of $33 \%$ ) with G. sihwensis. The physiological properties listed in Table 2 also readily distinguished the isolate from the two type strains. It is apparent from the results of phenotypic and genotypic studies that strain $\mathrm{SD} 29^{\mathrm{T}}$ represents a novel taxonomic unit
Table 1. Cellular fatty acid compositions (\%) of strain $\mathrm{SD} 29^{\top}$ and related type strains of the genus Gordonia

Strains: $1, \operatorname{SD}_{2} 9^{\mathrm{T}}$ (G. shandongensis sp. nov.); 2, G. alkanivorans DSM $44369^{\mathrm{T}} ; 3$, G. amicalis DSM $44461^{\mathrm{T}} ; 4$, G. desulfuricans DSM $44462^{\mathrm{T}}$; 5, G. hydrophobica DSM $44015^{\mathrm{T}}$; 6, G. namibiensis DSM $44568^{\mathrm{T}} ; 7, \quad$ G. rubripertincta DSM $43197^{\mathrm{T}} ; \quad 8, \quad$ G. sihwensis DSM $44576^{\mathrm{T}} ; 9$, G. terrae DSM $43249^{\mathrm{T}} ; 10$, G. westfalica DSM $44215^{\mathrm{T}}$. In addition, strain $\mathrm{SD} 29^{\mathrm{T}}$ contains $1 \% \mathrm{C}_{17: 1} \omega 8 \mathrm{c}$ and $1 \%$ $\mathrm{C}_{17: 0} 3-\mathrm{OH}$, and G. namibiensis DSM $44568^{\mathrm{T}}$ and G. rubripertincta DSM $43197^{\mathrm{T}}$ respectively contain 1 and $3 \% \mathrm{C}_{19: 1}$. Data in columns 2-4, 6, 8 and 10 were taken from Linos et al. (1999), and data in columns 5, 7 and 9 were taken from Kim et al. (2003).

\begin{tabular}{|lrrrrrrrrrr|}
\hline Fatty acid & $\mathbf{1}$ & $\mathbf{2}$ & $\mathbf{3}$ & $\mathbf{4}$ & $\mathbf{5}$ & $\mathbf{6}$ & $\mathbf{7}$ & $\mathbf{8}$ & $\mathbf{9}$ & $\mathbf{1 0}$ \\
\hline $\mathrm{C}_{14: 0}$ & 4 & 4 & 2 & 2 & 1 & 2 & 2 & 1 & 2 & 2 \\
$\mathrm{C}_{15: 0}$ & 1 & 1 & 3 & & 4 & 4 & 2 & 1 & 1 & 1 \\
$\mathrm{C}_{16: 1} \omega 7 c$ & 1 & & 1 & 1 & & & & 1 & & 12 \\
$\mathrm{C}_{16: 1} \omega 9 c$ & & 16 & 14 & 15 & 13 & 12 & 15 & 19 & 16 & \\
$\mathrm{C}_{15: 0}$ iso 2-OH & 15 & & & & & & & & & \\
$\mathrm{C}_{16: 0}$ & 36 & 28 & 29 & 26 & 27 & 24 & 25 & 39 & 32 & 32 \\
$\mathrm{C}_{17: 1} \omega 9 c$ & & 2 & 6 & & 4 & 8 & 5 & 2 & 1 & \\
$\mathrm{C}_{17: 0}$ & 1 & 1 & 5 & 1 & 4 & 7 & 3 & 1 & 1 & 2 \\
$10-$ Methyl $\mathrm{C}_{17: 0}$ & & & 2 & & 4 & 2 & 1 & & & \\
$\mathrm{C}_{18: 1}$ & 21 & 25 & 23 & 18 & 14 & 25 & 24 & 12 & 26 & 25 \\
$\mathrm{C}_{18: 0}$ & 1 & 2 & 2 & 7 & 1 & 2 & & 1 & 2 & 1 \\
TBSA & 15 & 20 & 13 & 30 & 26 & 12 & 17 & 22 & 19 & 17 \\
$\left(10\right.$-methyl $\left.\mathrm{C}_{18: 0}\right)$ & & & & & & & & & & \\
& & & & & & & & & & \\
\hline
\end{tabular}

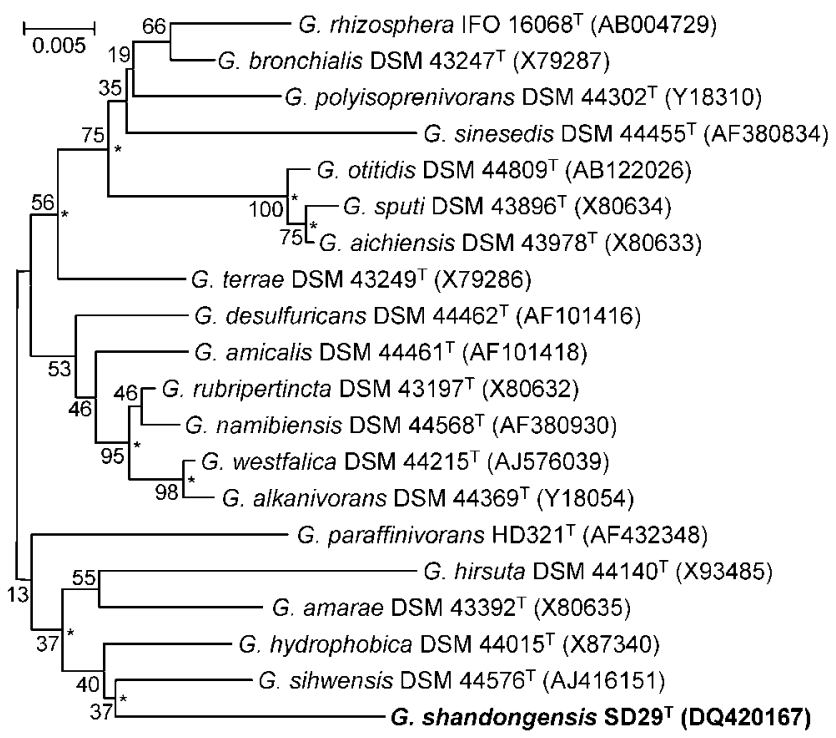

Fig. 1. Phylogenetic tree based on $16 \mathrm{~S}$ rRNA gene sequences created using the neighbour-joining method in MEGA version 3.1, showing the phylogenetic positions of strain $\mathrm{SD}_{2}{ }^{\top}$ and type strains within the genus Gordonia. Numbers at branching points refer to percentages of bootstrap values (from 1000 replications). Asterisks represent clades that were also recovered using the maximum-parsimony algorithm. Bar, $0.005 K_{\text {nuc }}$ value. 
Table 2. Physiological properties that distinguish strain $\mathrm{SD}_{29^{\top}}$ from the type strains of $G$. hydrophobica and $G$. sihwensis

Strains: 1, strain $\operatorname{SD}_{2} 9^{\mathrm{T}}$ (G. shandongensis sp. nov.); 2, G. hydrophobica DSM 44015 $; 3$, G. sihwensis DSM 44576 ${ }^{\mathrm{T}}$. +, Positive; -, negative; d, doubtful.

\begin{tabular}{|lccc|}
\hline Characteristic & $\mathbf{1}$ & $\mathbf{2}$ & $\mathbf{3}$ \\
\hline Utilization of sole carbon sources: & & & \\
D-Cellobiose & + & - & - \\
Sucrose & - & + & + \\
D-Galactose & $\mathrm{d}$ & + & + \\
D-Arabinose & + & - & - \\
D-Ribose & - & + & - \\
L-Alanine & - & + & - \\
L-Valine & - & + & + \\
L-Hydroxyproline & - & - & + \\
L-Arginine & - & + & - \\
Benzoate & - & - & $\mathrm{d}$ \\
Decomposition of guanine & + & - & - \\
Hydrolysis of urea & + & - & + \\
\hline
\end{tabular}

in the genus Gordonia. It is therefore proposed that the strain should be recognized as the type strain of a novel species with the name Gordonia shandongensis sp. nov.

\section{Description of Gordonia shandongensis sp. nov.}

Gordonia shandongensis (shan.dong.en'sis. N.L. fem. adj. shandongensis referring to Shandong Province, China, from where the type strain was isolated).

Gram-positive, aerobic, non-motile, slightly acid-fast actinomycete that fragments into rod/coccus-like elements. Colonies are light yellow and rough with irregular margins on ISP 2 agar. L-Proline is used as a sole carbon source for energy and growth but L-aspartate, L-rhamnose, sodium succinate, citric acid and sebacic acid are not. Aesculin is degraded but casein, starch, tyrosine and xanthine are not. Nitrate is reduced to nitrite. The organism grows well at $20-37^{\circ} \mathrm{C}$ and at $\mathrm{pH}$ 5.5-9.0. Other physiological properties are shown in Table 2. The cell wall chemotype is IV, and phospholipid type is PII. The principal menaquinone is MK$9\left(\mathrm{H}_{2}\right)$. The major fatty acids are $\mathrm{C}_{16: 0}(35.9 \%), \mathrm{C}_{18: 1} \omega 9 c$ (21.3\%), 10-methyl $\mathrm{C}_{18: 0}$ (TBSA) $(14.9 \%)$ and $\mathrm{C}_{15: 0}$ iso 2$\mathrm{OH}(14.6 \%)$. Mycolic acids are present.

The type strain, SD29 $\left(=\right.$ CGMCC $\left.4.3492^{\mathrm{T}}=\mathrm{JCM} 13907^{\mathrm{T}}\right)$, was isolated from farmland soil collected in Shandong Province, China.

\section{Acknowledgements}

This work was supported by the Knowledge Innovation Project of Chinese Academy of Sciences. The authors are grateful to Professor R. M. Kroppenstedt (DSMZ) for providing some type strains of Gordonia.

\section{References}

Chun, J. \& Goodfellow, M. (1995). A phylogenetic analysis of genus Nocardia with 16S rRNA gene sequences. Int J Syst Bacteriol 45, 240-245.

Collins, M. D. (1985). Isoprenoid quinone analysis in classification and identification. In Chemical Methods in Bacterial Systematics, pp. 267-287. Edited by M. Goodfellow \& D. E. Minnikin. London: Academic Press.

Felsenstein, J. (1985). Confidence limits on phylogenies: an approach using the bootstrap. Evolution 39, 783-791.

Fitch, W. M. (1971). Toward defining the course of evolution: minimum change for a specific tree topology. Syst Zool 20, 406-416.

Goodfellow, M., Isik, K. \& Yates, E. (1999). Actinomycete systematics: an unfinished synthesis. Nova Acta Leopold 312 (NF80), 47-82.

Gordon, R. E. (1967). The taxonomy of soil bacteria. In The Ecology of Soil Bacteria, pp. 293-321. Edited by T. R. G. Gray \& D. Parkinson. Liverpool: Liverpool University Press.

Gordon, R. E. \& Mihm, J. M. (1957). A comparative study of some strains received as nocardiae. J Bacteriol 73, 15-27.

Hasegawa, T., Takizawa, M. \& Tanida, S. (1983). A rapid analysis for chemical grouping of aerobic actinomycetes. J Gen Appl Microbiol 29, 319-322.

Huang, Y., Qi, W., Lu, Z., Liu, Z. \& Goodfellow, M. (2001). Amycolatopsis rubida sp. nov., a new Amycolatopsis species from soil. Int J Syst Evol Microbiol 51, 1093-1097.

lida, S., Taniguchi, H., Kageyama, A., Yazawa, K., Chibana, H., Murata, S., Nomura, F., Kroppenstedt, R. M. \& Mikami, Y. (2005). Gordonia otitidis sp. nov., isolated from a patient with external otitis. Int J Syst Evol Microbiol 55, 1871-1876.

Kageyama, A., lida, S., Yazawa, K., Kudo, T., Suzuki, S., Koga, T., Saito, H., Inagawa, H., Wada, A. \& other authors (2006). Gordonia araii sp. nov. and Gordonia effusa sp. nov., isolated from patients in Japan. Int J Syst Evol Microbiol 56, 1817-1821.

Kämpfer, M. \& Kroppenstedt, R. M. (1996). Numerical analysis of fatty acid patterns of coryneform bacteria and related taxa. Can J Microbiol 42, 989-1005.

Kim, S. B., Brown, R., Oldfield, C., Gilbert, S. C. \& Goodfellow, M. (1999). Gordonia desulfuricans sp. nov., a benzothiophene-desulphurizing actinomycete. Int J Syst Bacteriol 49, 1845-1851.

Kim, K. K., Lee, C. S., Kroppenstedt, R. M., Stackebrandt, E. \& Lee, S. T. (2003). Gordonia sihwensis sp. nov., a novel nitrate-reducing bacterium isolated from a wastewater-treatment bioreactor. Int J Syst Evol Microbiol 53, 1427-1433.

Kimura, M. (1980). A simple method for estimating evolutionary rates of base substitutions through comparative studies of nucleotide sequences. J Mol Evol 16, 111-120.

Klatte, S., Rainey, F. A. \& Kroppenstedt, R. M. (1994). Transfer of Rhodococcus aichiensis Tsukamura 1982 and Nocardia amarae Lechevalier and Lechevalier 1974 to the genus Gordona as Gordona aichiensis comb. nov. and Gordona amarae comb. nov. Int J Syst Bacteriol 44, 769-773.

Kumar, S., Tamura, K. \& Nei, M. (2004). MEGA3: integrated software for molecular evolutionary genetics analysis and sequence alignment. Brief Bioinform 5, 150-163.

Kummer, C., Schumann, P. \& Stackebrandt, E. (1999). Gordonia alkanivorans sp. nov., isolated from tar-contaminated soil. Int J Syst Bacteriol 49, 1513-1522.

Lechevalier, H. A. \& Lechevalier, M. P. (1980). The chemotaxonomy of actinomycetes. In Actinomycete Taxonomy (Special Publication no. 6), pp. 277-284. Edited by A. Dietz \& D. W. Thayer. Arlington, VA: Society of Industrial Microbiology. 
Lechevalier, M. P. \& Lechevalier, H. A. (1970). Chemical composition as a criterion in the classification of aerobic actinomycetes. Int J Syst Bacteriol 20, 435-443.

Lechevalier, M. P., De Bièvre, C. \& Lechevalier, H. A. (1977). Chemotaxonomy of aerobic actinomycetes: phospholipid composition. Biochem Syst Ecol 5, 249-260.

Linos, A., Steinbüchel, A., Spröer, C. \& Kroppenstedt, R. M. (1999). Gordonia polyisoprenivorans sp. nov., a rubber-degrading actinomycete isolated from an automobile tyre. Int J Syst Bacteriol 49, 1785-1791.

Maldonado, L. A., Stainsby, F. M., Ward, A. C. \& Goodfellow, M. (2003). Gordonia sinesedis sp. nov., a novel soil isolate. Antonie van Leeuwenhoek 83, 75-80.

Minnikin, D. E., Alshamaony, L. \& Goodfellow, M. (1975). Differentiation of Mycobacterium, Nocardia, and related taxa by thin-layer chromatographic analysis of whole-organism methanolysates. J Gen Microbiol 88, 200-204.

Minnikin, D. E., O'Donnell, A. G., Goodfellow, M., Alderson, G., Athalye, M., Schaal, A. \& Parlett, J. H. (1984). An integrated procedure for the extraction of isoprenoid quinones and polar lipids. J Microbiol Methods 2, 233-241.

Saitou, N. \& Nei, M. (1987). The neighbor-joining method: a new method for reconstructing phylogenetic trees. Mol Biol Evol 4, 406-425.

Sasser, M. (1990). Identification of bacteria by gas chromatography of cellular fatty acids. Technical Note 101. Newark, DE: MIDI Inc.

Shen, F.-T., Goodfellow, M., Jones, A. L., Chen, Y.-P., Arun, A. B., Lai, W.-A., Rekha, P. D. \& Young, C.-C. (2006). Gordonia soli sp. nov., a novel actinomycete isolated from soil. Int J Syst Evol Microbiol 56, 2597-2601.
Shirling, E. B. \& Gottlieb, D. (1966). Methods for characterization of Streptomyces species. Int J Syst Bacteriol 16, 313-340.

Soddell, J. A., Stainsby, F. M., Eales, K. L., Seviour, R. J. \& Goodfellow, M. (2006). Gordonia defluvii sp. nov., an actinomycete isolated from activated sludge foam. Int J Syst Evol Microbiol 56, 2265-2269.

Stackebrandt, E., Smida, J. \& Collins, M. D. (1988). Evidence of phylogenetic heterogeneity within the genus Rhodococcus: revival of the genus Gordona (Tsukamura). J Gen Appl Microbiol 34, 341-348.

Stackebrandt, E., Rainey, F. A. \& Ward-Rainey, N. L. (1997). Proposal for a new hierarchic classification system, Actinobacteria classis nov. Int J Syst Bacteriol 47, 479-491.

Takeuchi, M. \& Hatano, K. (1998). Gordonia rhizosphera sp. nov. isolated from the mangrove rhizosphere. Int J Syst Bacteriol 48, 907-912.

Tsukamura, M. (1971). Proposal of a new genus, Gordona, for slightly acid-fast organisms occurring in sputa of patients with pulmonary disease and in soil. J Gen Microbiol 68, 15-26.

Wu, C., Lu, X., Qin, M., Wang, Y. \& Ruan, J. (1989). Analysis of menaquinone compound in microbial cells by HPLC. Microbiology (Beijing) 16, 176-178 (in Chinese).

Xue, Y., Sun, X., Zhou, P., Liu, R., Liang, F. \& Ma, Y. (2003). Gordonia paraffinivorans sp. nov., a hydrocarbon-degrading actinomycete isolated from an oil-producing well. Int J Syst Evol Microbiol 53, 1643-1646.

Yoon, J.-H., Lee, J. J., Kang, S.-S., Takeuchi, M., Shin, Y. K., Lee, S. T., Kang, K. H. \& Park, Y.-H. (2000). Gordonia nitida sp. nov., a bacterium that degrades 3-ethylpyridene and 3-methylpyridine. Int J Syst Evol Microbiol 50, 1203-1210. 